\title{
PERSONAL RECOLLECTIONS OF SOME EARLY SASKATCHEWAN NATURALISTS
}

\author{
by Robert D. Symons, Silton
}

Today's ornithologists and birdwatchers, professional or amateur, undoubtedly owe much to men of an older generation, who began to describe the varied bird life of our province and neighbouring areas. Dr. Stuart Houston has in these later years done yeoman service to the birders of Saskatchewan in unearthing information regarding the much earlier ornithologists who worked the Saskatchewan field, especially during the regime of the Hudson's Bay Company. Yet there is something of a gap between these pioneers and the many bird people of today; into this gap I am happy to press a few recollections of amateurs and others whom I have known personally. Perhaps the greatest contribution made by many of these people was not so much by way of intensive research, as by awakening and encouraging public awareness of the beauty and value of our native birds. We must appreciate that in the early 1900's and in the 1920's neither transportation nor communication as we know them - and much less time and money - were available. The average settler - like Spencer Pierce - was struggling for a toe-hold, and it is greatly to the credit of such people that they maintained their interest in a subject that brought no return except the priceless satisfaction of understanding and appreciating their surroundings.

(1) The first Saskatchewan bird man I met (when I was 12) was the late Rex Holmes. He was then back in England in his country home after a number of years in Canada. He had been one of the original Boon Colonists and had settled some miles north of the present Lloydminster. The little whistle-stop of Rex is named for him. He spent a good deal of his time hunting, but especially "birding", camping for weeks in the Onion Lake and Bronson Forest areas. He took many beautiful specimens which he sent to Roland Ward, London, for mounting and for storing in England. When I knew Rex his roomy study contained birds and mammals. I particularly remember sitting for hours drawing Gray Jays, Great Horned Owls, godwits, Pileated Woodpeckers and in particular a Yellow-headed Blackbird (or as he had it labelled"Troupial"). Towards the end of World War I Rex went to Tanganyika. From there he contributed to the Museum at Nairobi, and was of assistance to Colonel Meinertzhagen who was preparing his classic work on the birds of East Africa. Rex is buried in Tanganyika, and after his death the birds were taken into the care of the Museum of Natural History at South Kensington, London. In one of his last letters to me, after I came to Saskatchewan, Rex said in part "There are many beautiful birds here (S. Africa) but they do not compare with the quite enchanting if less brightly-hued ones you will be encountering; nor does camel thorn and elephant grass provide such a romantic surrounding as the sparkling sloughs and green groves of the Saskatchewan country."

(2) In 1914, after my arrival in Canada, I made the acquaintance of the late Dr. H. IM. Speechly of Pilot Mount, Manitoba, first by reading his nature column in the old Grain Growers Guide (now the Country Guide), and very soon by correspondence. I had no "bird book", but used to make coloured sketches of all the birds I saw, and these I sent to him for identification. He always replied in the most courteous and encouraging terms, naming my birds and giving me additional information. $\mathrm{He}$ was a country doctor of the old school, visiting his patients by horse and buggy. Not only a bird man, he was equally keen on botany and an 
acknowledged expert on farm weeds, deploring the spread of alien species introduced by settlers, and ably assisting the budding Manitoba Department of Agriculture.

In one of his letters to me he gave a vivid description of some of his drives at early dawn, listing the species he had observed, besides describing the roadside scene in general, and the glorious morning salute of the birds against a prairie sunrise. Reading this, you could hear the marsh birds' cries and the clip-clop of his horse. Dr. Speechly was, he said of himself, just a "humble roadside naturalist." $\mathrm{He}$ is long since dead but I have been in correspondence with his widow and his daughter.

(3) Not long after my arrival in Canada (in the winter of 1915-16 to be specific) and while in training with the Canadian Expeditionary Force in the old Winter Fair Building in Regina, I met Fred Bradshaw, then Chief Game Guardian with the Department of Agriculture. He used to give "bird talks" at the City Hall and at various points in the province. I always attended these when possible. Bradshaw used the Audubon "bird charts and a magic lantern. He had already started the nucleus of a museum with cases of mounted birds and some uncased mammals, which were displayed in the corridor of the Normal School Building in Regina (now part of the University of Saskatchewan).

Bradshaw-often with Neil Gilmour - travelled many long miles by buggy or Model T Ford all over the province, but particularly the southwestern cow-country, exhorting and encouraging the ranchers and settlers to help preserve our wild life, especially (in the Prince Albert area) the Wapiti, and in the Cypress Hills area, the Antelope and Sage Grouse. Very aware of the perils besetting what he called "our finest bird" - the Whooping Crane, he also began to make public his fears for their continuation and corresponded extensively with many



Fred Bradshaw (left) and H. Hedley Mitchell,

Photo by Fred G. Bard, Sask. Museum of Natural History

Rush Lake, Sask., 1928 
people, sending out hundreds of small booklets explaining the specific differences between these birds and swans, Snow Geese and pelicans. He finally relinquished his position with the Game Branch when it was transferred to Railways, Labour and Industry (!), and became the first Director of the Museum. Some of his letters contain references of great interest, such as "a mockingbird in full glorious song at Wilcox", and "a little colony of Sharp-tailed Sparrows nesting on the golf course at Regina."

Bradshaw, a tall gangling Yorkshireman with a shock of white hair, was always extremely sceptical of reports of new birds, and always demanded very definite proof, as this writer well remembers. He wrote several articles for the $\mathrm{C}$ anadian Field Naturalist. He also arsisted in drafting a number of laws relevant to conservation - a cause to which he was keenly dedicated. He died in Victoria, B.C. in 1956.

(4) At this time I also met the late Hedley Mitchell, the Museum preparator, another man of great charm, much humility and wide knowledge. Born in England he came to Canada to follow his beloved birds, and was engaged by the National Museum to make field trips and prepare skins. $\mathrm{He}$ told me that he was once chased off the Six-nations reserve by angry Indians who asked him if he did not know it was an offence against the Manito to shoot small song birds unless one was starving! "In my heart", he added, "I echo those sentiments; but this was my bread and butter!" Always ready to encourage, to share information, and with a tremendous capacity for living, this good-natured and humorous man was also a good preparator and a keen observer. We are all more or less familiar with Mitchell's Catalogue of Saskatchewan Birds, a very real contribution to the scanty literature of those days. The Museum certainly owes a great deal to Mitchell who prepared some of the early cases of birds in habitat with a dedicated joy. He retired in 1932 to Victoria, B.C.
(5) Two men who might be mentioned here are Mr. George Lang of Indian Head, and Mr. Angus Buchanan who did extensive field work in the Churchill River area. The two Barrenground Caribou in the present Museum were taken by the latter, among other specimens. Mr. Lang, who was Superintendent of the Indian Head Forestry farm, observed-if I am not mistaken - several uncommon species of birds, including the Scarlet Tanager and and Stellar's Jay. However, as I only met these two gentlemen very briefly, I should not enlarge on their activities, as there are others far better informed about them.

(6) I had earlier met Spencer Pierce of Ravenscrag in the Cypress Hills, and had spent more than one evening with him and his sisters in their ranch house in its lovely coulee setting. Even so, there are again others (like Fred Bard) who are far more capable of writing about this knowledgeable and kindly man than myself. $\mathrm{His}$ records are in general, I believe, to be found in 'Mitchell's "Catalogue." To me then, he was above all, another source of inspiration and encouragement. (Laurence Potter I never met, by the way, although he was a keen observer for years in this same area.)

(7) Neil Gilmour of Moose Jaw I did not meet until about 1926 or 1927 , although I had heard much of him previously. He was one of the early Game Guardians under Bradshaw, but above all he was a bird man. I am not aware that he wrote on the subject, other than his reports to his Chief. He worked chiefly the south and west parts of the province. His report on finding the last known nest of the Whooping Crane near Kerrobert is well written, with considerable detail. (See Can. Field Nat.) It was closely followed as to habitat and terrain in making up the museum case of the Whooping Cranes, and was a most valuable aid. Neil was another dedicated man whose work was in the nature of a labour of love, for the mere pittance such men received could not otherwise repay them for the long hours they spent in the field and expo- 
sure to the elements in open vehicles. Gilmour spoke in hundreds of rural schools and was indefatigable in spreading the gospel of conservation.

(8) It was in 1926 also, that I first met Fred Bard, the present Museum Director. Fred was then assistant to Mitchell, and it was under the latter's able direction that he himself became a highly skilled taxidermist. After Mitchell's retirement, Fred took over all the preparation of skins and cases, even painting the background. I have in mind particularly a case of jack rabbits in winter in which the background shows a farmer pulling away from a straw stack with a team and a rack load of fodder. It is interesting to reflect that today it would be impossible to duplicate that scene! Fred's grandfather had been a taxidermist in England and his father was a member of the Royal Northwest Mounted Police, but also keenly interested in wildlife, so clearly this interest ran in the family. Fred and I, under the direction of Bradshaw, put on the first wildlife exhibits at the Regina and Saskatoon Fairs in 1927 -I think I painted some panels of birds, against which we posed mounted specimens, and on a table in front was displayed as much of the free literature of the day (in pamphlet form) as was available. It was hot, tiring work sitting on camp chairs in a tent. I think we each received $\$ 75.00$ a month and a maintenance allowance of $\$ 2.00$ per day for board and room. But we kept our moss cool with water, and I remember Lady Lake (who was on a visit to the Prairies) asking permission to rest in one of our camp chairs while we poured cold water on her hot, tired feet!

Early in the Depression years the Museum came under the new Department of Natural Resources with Fred Dunk as Director, but its development was impeded by lack of funds. A greater blow was to come as a result of Hitler's war, for the Normal School Building was required for the use of the Military. The whole collection was put into cold storage in a dilapidated warehouse with Fred Bard as caretaker.
There it remained for several years. Fred used to go daily, fire up a little old wood and coal heater, and do his best to preserve the collections from dirt and damp. Not a very encouraging employment. When the war was over the exhibits were taken back to the original building (by now used by the Department of Public Health), and housed in the basement. It was from this point that the institution began to expand, since money gradually became more easily available, and public interest more greatly aroused. We all know what has been accomplished since those days.

But I think of Fred more especially as a splendid companion in the field. I camped with him at the Cochin Narrows, where he found Forster's Tern nesting, as well as on the Carrot River, where we watched the evening flights of the Chimney Swifts. Once, on the Nelson flats at Battleford, we were chased by a bull. The animal objeated to Fred snooping around with his camera, and probably thought this strange man-creature with a tripod and black head cloth meant no good by his harem! I am short-legged, and could not keep up with Fred's long strides and said "keep a-going!", but he said "never", and turning, levelled his camera and tripod at the bull, who paused long enough to allow us to gain the shelter of some trees.

There would be no object in my writing about Fred's contribution to our knowledge of Saskatchewan birds, for we are all aware of it.

(9) I should like to mention very briefly a few other men. One is Dewey Soper (now of Edmonton) who brought back much information from his biological survey of the International Boundary. Soper constantly urged me to write about birds, in particular the birds of the Cypress Hills and the Pasquia Hills-Cumberland House area.

There was also Mr. H. P. Gordon, who had an exhibit of mounted specimens (which I saw in the early '30's) in the Physics Building in the University at Saskatoon, just below Gus Kenderdine's studio. He was an oldish 
man whose scientific knowledge was limited but whose interest was great. I remember he had a male and a female Marsh Hawk mounted together, labelled respectively "the Grey Harrier" and "the Brown Harrier"(!) which gives him away as another Englishman! Yet still he aroused a great deal of interest among university students and I am sure his efforts were not wasted. I remember that Kenderdine made a portrait of the old gentleman in oils, the said gentleman in the act of mounting a magpie, if I remember rightly. How many readers of the Blue Jay remember this man who was called "The Naturalist?"

Finally, the late Barny Lindner, rancher at the Middle Fork, Cypress Hills. He never could have thought of himself as a "naturalist" or even a "bird lover" (!), nor did he ever put pen to paper, but he had an astonish- ing knowledge of the birds and animals of the Cypress Hills and the short-grass plains. Many were the trips we made together and many were the nests of Sage Grouse we discovered on his Middle Fork flats. $\mathrm{He}$ was a realistic conservationist, and he would never allow coyote hunters within his extensive fenced lease, for he held that coyotes were part of range ecology and did far less harm than the hunters.

We may feel reasonably assured that, under the inspiration of these, and many more not mentioned for lack of space, there are a goodly number of young people in our Province who will feel proud and happy to carry on in the footsteps of those who work for knowledge, appreciation, and conservation today. I feel personally privileged to have known well and to have worked with some of yesterday's birders.

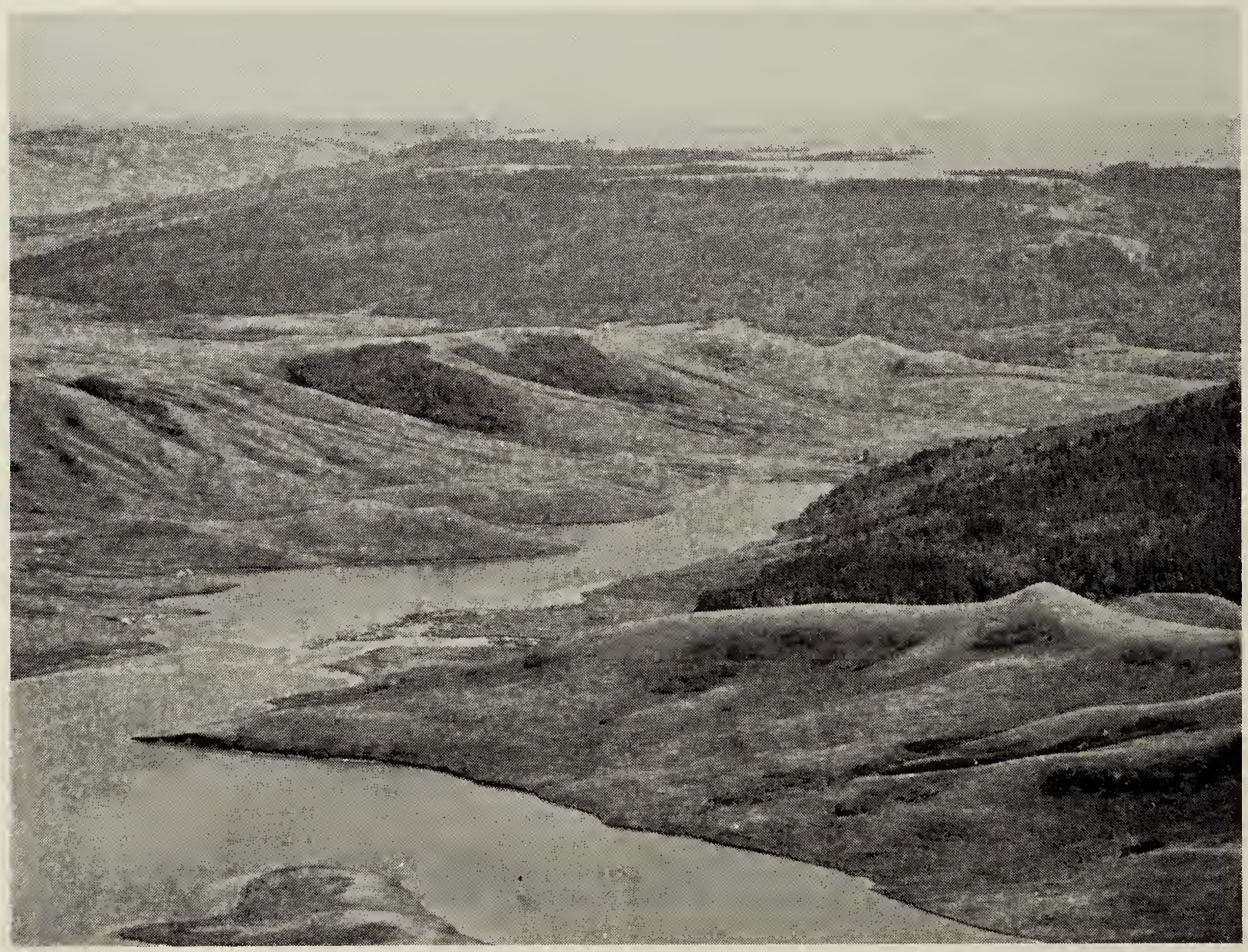

Aerial view of Cypress Hills

Sask. Govt. Photo 